\title{
ASUHAN KEPERAWATAN PADA DIARE AKUT DEHIDRASI SEDANG FOKUS STUDI KEKURANGAN VOLUME CAIRAN DI RSUD TEMANGGUNG
}

\author{
Nursing Care In Acute DiarrheaWith Midle Dehydrated Focusing Study Of Deficite \\ Fluid Volume In Temanggung Hospital
}

\author{
Yufita Wahid Hidayah \\ Poltekkes Kemenkes Semarang \\ yufitawahidhidayah@gmail.com
}

\begin{abstract}
ABSTRAK
Pendahuluan : Diare merupakan pengeluaran tinja yang tidak normal, frekuensi lebih dari 3 kali dengan atau tanpa lendir darah. Tujuan dari penlitian ini adalah memberikan penjelesan terkait profil pasien, tindakan yang diberikan kepada pasien baik farmakologi maupun non farmakologi dan berpa lama pasien dilakukan perawatan. Metodologi Metode penulisan dalam studi kasus ini menggunakan metode deskriptif yang menggambarkan proses asuhan keperawatan yang berfokus pada klien keperawatan dengan diare dehidrasi sedang dengan fokus pada studi defisiensi volume cairan. Hasil setelah perawatan 3x24 jam kekurangan volume cairan bisa diatasi jadi An. H mengalami peningkatan kesehatan yang ditandai oleh orang-orang dari bab pertama 5 kali sehari hingga 1 x sehari. Kesimpulan asuhan keperawatan yang dilakukan pada pasien dengan diare akut dehidrasi sedang dengan masalah kekurangan volume cairan mengalami peningkatan kesehatan di tandai dengan dari yang awalnya BAB 5 x sehari menjadi 1 x sehari dan dari yang awalnya mual,munta,lemes setelah dilakukan tindakan selama 3 hari menjadi mual muntah tidak ada dan lemas berkurang.
\end{abstract}

Kata kunci : Diare Akut, Dehidrasi Sedang, Kekurangan Volume Cairan

\section{ABSTRACK}

Introduction : Diarrhea is an abnormal stool expenditure, frequency more than 3 times with or without blood mucus. The purpose of this study is to provide an explanation regarding the patient's profile, the actions given to patients both pharmacological and non-pharmacological and the length of time the patient is treated

Method : The writing method in this case study uses a descriptive method that describes the process of nursing care that focuses on nursing clients with moderate dehydrated diarrhea with a focus on the study of fluid volume deficiency. Result: after treatment $3 \times 24$ hours lack of fluid volume can be overcome so An. H has a health improvement characterized by people from the first chapter 5 times a day to $1 x$ a day.

Discussion/Conclusion: Nursing care performed on patients with acute diarrhea with dehydration with a lack of fluid volume has improved health, marked by those who initially defecate 5 daily to $1 x$ a day and from the initial nausea, munta, lemes after 3 days of nausea. no vomiting and weakness.

Keywords : Acute Diarhea, Middle Dehydration, Deficite of Electrolize

\section{PENDAHULUAN}

Diare adalah suatu kondisi dimana seseorang buang air besar dengan konsistensi lembek atau cair, bahkan dapat berupa air saja dan frekuensinya lebih sering (lebih dari tiga kali) dalam satu hari. Survei Kesehatan Nasional tahun 2006 menempatkan diare pada posisi tertinggi kedua sebagai penyakit paling berbahaya pada balita. Diare dilaporkan telah membunuh 4 juta anak setiap tahun di negara-negara berkembang (Kemenkes RI, 2010).
Penyakit diare sering dijumpai pada anak-anak. Menjelang akhir dekade milenium ketiga ini, diare pada anak dibawah usia lima tahun masih menjadi penyebab kedua kematian di dunia. Hampir setiap tahun diare membunuh sekitar 525 ribu anak di usia tersebut, dan secara global kasus diare pada masa bayi setiap tahunnya mecapai angka 1,7 milyar (WHO, 2017).

Diare masih menjadi salah satu masalah kesehatan masyarakat yang perlu mendapat perhatian karena angka morbiditas 
dan mortilitasnya masih tinggi. Data dari Riskesdas 2007 menyebutkan bahwa penyakit diare dari tahun ke tahun masih menjadi penyebab utama kematian bayi dan balita di Indonesia (Anggraeni dan Farida, 2011). Di dunia sekitar lima juta anak meninggal dunia karena diare akut, dimana sebagian besar terjadi di negara berkembang termasuk Indonesia (Widoyono, 2011).

Beberapa survei menunjukkan bahwa diare masih menjadi penyebab kematian balita (Kemenkes,2011). Menurut SKRT 2001 menyebutkan angka mortilitas balita mencapai 13\%; Studi Mortalitas Dunia 2005 menyebutkan angka mortilitas anak karena diare sebanyak 17\%; WHO (Asia) sebesar 15\%; dan Riskesdas 2007 menyebutkan angka mortilitas karena diare balita (1-4 tahun) sebesar 25,2\% (Kemenkes, 2011).

Pada tahun 2013 angka kejadian diare di JawaTengah mencapai 1.407.082 dengan angka kematian berjumlah 62 orang dan 13 $\%$ kematian terjadi di kota Banyumas (Profil Kesehatan Jawa Tengah, 2013)

Secara klinis penyebab diare dapat dikelompokkan dalam 6 golongan besar yaitu infeksi (disebabkan oleh bakteri, virus atau infestasi parasit), malabsorpsi, alergi, keracunan, imunodefisiensi dan sebab-sebab lainnya. Penyebab yang sering ditemukan di lapangan ataupun secara klinis adalah diare yang disebabkan infeksi dan keracunan (Departemen Kesehatan RI, 2011).

Kelompok umur yang paling rawan terkena diare adalah kelompok anak usia balita. Pada usia ini, anak mulai mendapat makanan tambahan seperti makanan pendamping dan susu formula, sehingga kemungkinan termakan makanan yang sudah terkontaminasi oleh agen penyebab penyakit diare menjadi lebih besar (Hiswani, 2003). Selain itu beberapa faktor yang dapat memicu kerentanan terhadap diare pada bayi dan anak-anak, antara lain: pemberian ASI kurang dari 2 tahun, kekurangan gizi, imunodefisiensi, imunosupresi, faktor lingkungan dan faktor prilaku (Adisasmito,2007).

Tata laksana di rumah maupun di sarana kesehatan sangat mempengaruhi keselamatan jiwa anak yang menderita diare terutama dengan dehidrasi (Mafazah, 2013).

Pemberian cairan adalah yang utama pada penderita diare karena sebagian besar kasus terutama anak-anak yang dibawa ke rumah sakit sudah terjadi komplikasi berupa dehidrasi sehingga diperlukan cairan rehidrasi yang sesuai. Pemberian cairan untuk rehidrasi yang direkomendasikan WHO adalah cairan rehidrasi oral yaitu oralit 200 yang diberikan pada kasus diare dengan dehidrasi ringan-sedang yang efektif untuk mengembalikan cairan dan juga menurunkan volume feces serta menurunkan muntah (Depkes, 2008) Salah satu faktor resiko terjadinya diare pada anak adalah keracunan makanan. Keracunan makanan tersebut disebabkan karena anak mengkonsumsi makanan yang tidak terjamin kebersihannya (Wong, 2009).

Resiko akibat diare dapat dikurangi dengan terapi yang tepat. Terapi pertama bagi penderita diare akut tanpa dehidrasi, dan dehidrasi ringansedang adalah dengan pemberian CRO (cairan rehidrasi oral). Pemberian CRO yang tepat dengan jumlah yang memadai merupakan modal yang utama mencegah dehidrasi. Terapi lain yang dapat diberikan adalah adsorben (attapulgit dan pektin), dan antiemetik (metoklopramid, domperidon, dan ondansentron). Pemberian antibiotik hanya diindikasikan pada keadaan tertentu seperti diare yang terindikasi infeksi patogen serta diare pada bayi dan anak dengan keadaan immunocompromised (Gunawan, 2007).

Kebersihan dalam kehidupan seharihari merupakan hal yang sangat penting dan harus diperhatikan karena kebersihan akan mempengaruhi kesehatan seseorang. Seseorang mengalami sakit, biasanya masalah kebersihan kurang diperhatikan, hal ini terjadi karena menganggap bahwa masalah kebersihan diri adalah masalah sepele, padahal jika hal tersebut dibiarkan dapat mempengaruhi kasehatan secara umum bisa menyebabkan penyakit seperti diare (Tarwoto dan Wartonah, 2008). Kebersihan lingkungan pada hakekatnya adalah kondisi atau keadaan lingkungan yang optimum sehingga berpengaruh positif terhadap status kesehatan yang optimum. Ruang lingkup kebersihan lingkungan antara lain mencakup : perumahan, pembuangan kotoran manusia (tinja), penyediaan air bersih, pembuangan sampah, pembuangan air kotor (air limbah), rumah hewan ternak (kandang) dan sebagainya (Anwar, 2003). 


\section{METODE}

Metode penulisan pada studi kasus ini menggunakan metode deskriptif yaitu menggambarkan tentang proses asuhan keperawatan yang memfokuskan pada salah satu masalah penting dalam kasus yang dipilih yaitu asuhan keperawatan klien dengan diare akut dehidrasi sedang dengan fokus studi kekurangan volume cairan. kriteria dari responden adalah klien yang menglami diare akut dehidrasi sedang dan memiliki tanda kekurangan volume cairan. Sampel dari penelitian ini adalah anak An $\mathrm{H}$ dengan usia 9 bulan di RSUD Temanggung.

\section{HASIL DAN PEMBAHASAN}

Responden dalam penulisan ini adalah klien An. H dengan usia 9 bulan, berjenis Kelamin Laki -laki, beragama Islam dan beralamat di Temanggung. Klien tinggal bersama ibu dan Ayahnya. Pada hari Senin tanggal 15 januari 2018 pada pukul 21.05 WIB, telah dilakukan pengkajian terhadap An. $\mathrm{H}$ dan didapatkan data subjektif yaitu ibu klien mengatakan bahwa klien BAB 5 kali sehari dengan konsistensi cair dengan sedikit ampas dan klien muntah, minumnya sedikit. Sedangkan pada data objektif didapatkan data klien terlihat lemas,mukosa bibir kering, mata sedikit cekung, dan bising usus $24 \mathrm{x} /$ menit.

Berdasarkan analisa data yang dilakukan pada tanggal 15 Januari 2018 pada pukul 21.05 WIB. Didapatkan diagnosa keperawatan prioritas yaitu kekurangan volume cairan berhubungan dengan kehilangan cairan ditandai dengan kelemahan dan kulit kering.

Didapatkannya diagnosa diatas, maka akan dilakukan asuhan keperawatan dengan tujuan umum yang akan di capai yaitu setelah dilakukan tindakan keperawatan selama $3 \mathrm{x}$ 24 jam diharapkan kekurangan volume cairan dapat teratasi dengan kriteria hasil tidak terdapat tanda tanda dehidrasi, mukosa bibir lembab, ttv dalam batas normal, turgor kulit normal.

Tindakan keperawatan untuk mengatasi maslah keperawatan pada An. H dengan diagnosa keperawatan kekurangan volume cairan, penulis menggunakan rencana keperawatan menurut buku NIC edisi keenam yaitu dengan monitor tanda tanda vital pasien, tentukan riwayat diare, monitor anda tanda dehidrasi, tentukan input output klien, instruksikan keluarga untuk memberitahu setiap kali mengalami diare. Sehingga dapat membatu mengetahui perkembangan klien.

Implementasi hari pertama dilakukan pada pukul 21.05 WIB yaitu diawali dengan memonitor TTV(tanda tanda Vital) klien dengan hasil nadi : $102 \mathrm{x} /$ menit, suhu : $36^{5^{\circ} \mathrm{C}}$ ,respirasi rate : $23 \mathrm{x} /$ menit dan ibu klien mengatakan klien masih lemas dan BAB 5 kali perhari, berwarna kuning dengan sedikit ampas. Selanjutnya menentukan riwayat diare dengan hasil ibu klien mengganti pempers 5 kalo sehari, memonitor input dan output cairan denga hasil balance cairan = $120,5 \mathrm{cc}$, memonitor tanda dehidrasi pada pasien dengan hasil mukosa bibir kering, turgor kulit tidak elastis, mata sedikit cekung. Evaluasi yang didapat pada hari pertama yaitu ibu klien mengatakan anakanya masih merasa lemas dan $\mathrm{BAB} 4$ kali sehari dengan nadi : $102 \mathrm{x} /$ menit, suhu : $36^{5^{\circ} \mathrm{C}}$,respirasi rate : $23 \mathrm{x} /$ menit. Dengan lanjut intervensi monitor ttv dan monitor input dan output cairan.

Implementasi hari kedua penulis memonitor tnada tanda vital di mulai pada jam 15.00 WIB pada tanggal 16 Januari 2018 dengan haasil perkembangan klien suhu : $36^{6 \circ} \mathrm{C}$, nadi :101 x /menit dan RR : 22x/ menit. Sedangkan pada pukul 16.00 memonitor input dan output cairan klien dengan input cairan $770 \mathrm{CC}$ dan output cairan klien 260 CC dan ibu klien mengatakan $\mathrm{BAB} 2$ kali sehari dengan konsistensi sdikit cair. Evaluasi yang didapat pada hari kedua yaitu ibu klien mengatakan anaknya mual muntahnya sudah berkurang, lemes berkurang dengan nadi $102 \mathrm{x} / \mathrm{menit}$, suhu : $36^{5^{\circ}} \mathrm{C}$ dan RR : $23 \mathrm{x} /$ menit dengan tindakan lanjutnya monitor TTV dan monitor input dan output cairan.

Implementasi hari ketiga pada tanggal 19 Januari 2018 pukul 09.00 WIB penulis memonitot TTV klien dengan hasil

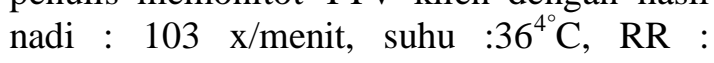
$22 x / m e n i t$, dan memonitor input dan output cairan dengan hasil input yang terdiri dari makan,minm dan infus : $900 \mathrm{CC}$ dan output yang terdiri dari BAK da BAB $380 \mathrm{cc}$ lembek,berampas dan 1 klai dalam sehari. dan ibu klien mengatakan anaknya makan dan minumnya lumayan banyak, sudah tidak muntah lagi. Evaluasi yang didiapat pada hari ketiga adalah klien BAB 1 x sehari, sudah 
tidak lemas, makan dan minum sudah mau. Nadi 103 x /menit, RR : 22x/menit, dan suhu $35^{4 \circ} \mathrm{C}$.

Dari kesimpulan evaluasi diatas dapat terlihat bahwa dari hari pertama - hari ketiga An $\mathrm{H}$ mengalami peningkatan perkembangan kesehatannya.

\section{KESIMPULAN}

Dari hasil penelitian didapatkan kesimpulan bahwa

a. Pengkajian

Asuhan keperawatan yang dilakukan pada An. $\mathrm{H}$ dan dihasilkan data BAB $5 \mathrm{x}$ sehari konsistensi caira dan sedkit ampas,merasa lemas, dan mual muntah,mukosa bibir kering yang menandakan bahwa klien megalami kekurangan volume cairan.

b. Tindakan Keperawatan

Tindakan keperawatan yang diberikan terhadap klien yaitu memonitor TTV, memonitor Input dan Output cairan,memonitor tanda dehidrasi penulis mengatakan bahwa dilakukan tindakan keperawatan tersebut Untuk mengetahui kondisi perkembangan kesehatan klien.

c. Evaluasi

Dalam melakukan evaluasi tindakan keperawatan, penulis menganaslisis dari tindakan keperawatan yang dilakuka penulis, setelah di evaluasi An.H mengalami peningkatan kesehatan di tandai dengan dari yang awalnya BAB $5 \mathrm{x}$ sehari menjadi $1 \mathrm{x}$ sehari dan dari yang awalnya mual,munta,lemes setelah dilakukan tindakan selama 3 hari menjadi mual muntah tidak ada dan lemas berkurang.

\section{SARAN}

a. Bagi Rumah Sakit

Diharakan perawat lebih meningkatkan komunikasi terpeutiknya dan doharapkan pasien dan keluarga dapat bersama sama ikut serta dalam upaya peningkatan dan mempeertahankan kesehatan klien.

b. Bagi Peneliti Lain

Diharapkan penelitian ini dapat menjadi referensi lain serta untuk dapat dikembangkan dalam memberikan asuhan keperawatan pada pasien denga Diare akut dehidrasi.

\section{DAFTAR PUSTAKA}

Bulechek, Gloria M (2013) Nursing Interventions Classification(NIC) edisi keenam. Jakarta. Elsevier

Christy, M. Y. (2014). Faktor Yang Berhubungan Dengan Kejadian Dehidrasi Diare Pada Balita Di Wilayah Kerja Puskesmas Kalijudan. Jurnal Berkala Epidemiologi.

Herdman, T Hether(2015). Diagnosis Keperawatan definisi dan klasifikasi 2015-2017 edisi 10. Jakarta : EGC

Indriyani Puji, Kurniawan1Yuniar Deddy (2017). Pengaruh oralit 200 terhadap lama perawatan bayi dengan diare akut dehidrasi ringan-sedang. Prosiding Seminar Nasional Publikasi HasilHasil Penelitian dan Pengabdian Masyarakat

Jacobs, C., Manoppo, J., \& Warouw, S. (2013). Pengaruh oralit WHO terhadap kadar natrium dan kalium plasma pada anak diare akut dengan dehidrasi. Jurnal E-Biomedik (EBM).

Kemenkes RI (2011) Buletin Jendela data dan informasi kesehatan. Jakarta

Mafazah, L.( 2013). Ketersediaan sarana

sanitasi dasar, personal hygine ibu dan kejadian diare.Jurnal Kesetahan masyarakat.Vol.8.No.2.176-182

Moorhead,Sue \& Johnson,Marion (2013). Nursing Outcomes Classification(NOC) edisi 5. Jakarta Elsevier

Profil Kesehatan Jeteng (2013) Profil kesehatan provinsi Jawa Tengah 2013

Siswidiasari, A., Astuti, K. W., \& Yowani,S.C. (2014). Profil terapi obat pada pasien rawat inap dengan diare akut pada anak di Rumah Sakit Umum Negara. Jurnal Kimia 8. 